\title{
Las cofradías religiosas: aproximación a su papel en la crea- ción artística en la Cantabria de la Edad Moderna
}

\section{The religious brotherhoods: approach to his role in artistic creation in the Cantabria of the Modern Age}

\section{Eduardo Gómez Rodríguez}

\author{
Universidad de Cantabria \\ Máster en Patrimonio Histórico y Territorial \\ Facultad de Filosofía y Letras. Edificio Interfacultativo \\ Avda. de los Castros, 52. 39005 - Santander \\ edug33@gmail.com \\ ORCID: https://orcid.org/0000-0002-2202-2134
}

Fecha de envío: 30/09/2018. Aceptado: 29/10/2018.

Referencia: Santander. Estudios de Patrimonio, 1 (2018), pp. 233-256.

ISSN 2605-4450 (ed. impresa) / ISSN 2605-5317 (digital)

Resumen: Tras el Concilio de Trento en el que se fija el dogma de la Iglesia Católica Romana al tiempo que se pretende transmitir dicho dogma por todo el orbe católiCo, renuevan su importancia las cofradías religiosas quienes contribuirán a unificar la práctica religiosa en el seno de la Iglesia y a fomentar la devoción, además de convertirse en uno de los patrocinadores de la creación artística. Una vez contextualizado espacio-temporalmente este hecho, se estudiarán algunos ejemplos de cómo las cofradías participaron en el enriquecimiento artístico de sus parroquias, qué elementos encargaron y con qué finalidad.

Palabras clave: cofradías religiosas; Cantabria; creación artística; Concilio de Trento.

Abstract: After the Council of Trent in which the dogma of the Roman Catholic Church is fixed while it is intended to transmit this dogma throughout the Catholic orb, they renew their importance the religious brotherhoods who will contribute to unify the religious practice in the bosom of The church and to promote devotion, in addition to becoming one of the sponsors of artistic creation. Once is contextualized space-temporarily this fact, some examples of how the brotherhoods participated in the artistic enrichment of their parishes will be studied, what elements they commissioned and for what purpose.

Keywords: Religious brotherhoods; Cantabria; artistic creation; Council of Trent.

\section{INTRODUCCIÓN}

Uno de los periodos más prolíficos en la creación artística religiosa fue el que siguió al Concilio de Trento que, celebrado entre los años 1545 y 
1563, definió los dogmas y fijó los modelos de fe y las prácticas religiosas de la Iglesia Católica hasta mediados del siglo XX. Para el objetivo del presente artículo, que consiste en hacer una aproximación al papel que desempeñaron algunas de las Cofradías religiosas de Cantabria ${ }^{1}$ en la creación artística, hay que tener en cuenta, de manera especial, lo que en dicho Concilio se decide en lo relativo al culto, aspecto éste que fue tratado en la sesión XXV celebrada en diciembre de 1563 y donde se refuerza el papel mediador de los santos así como la importancia de la representación iconográfica como instrumento de propagación de la fe ${ }^{2}$.

El marco territorial que vamos a estudiar se corresponde con el espacio geográfico conocido históricamente como "Montañas de Burgos", territorio controlado eclesiásticamente por el arzobispado de Burgos hasta mediados del siglo XVIII ${ }^{3}$. Los territorios que dicho arzobispado incluía aparecen delimitados por Barrón García ${ }^{4}$ pudiéndose

1 El papel de las cofradías como estimuladoras de la creación artísticas no es exclusivo de Cantabria. Sirvan de ejemplo las actuaciones que en este sentido hacen los cofrades granadinos y que aparecen recogidos en ARIAS DE SAAVEDRA ALÍAS, Inmaculada y LÓPEZ-GUADALUPE MUNOZ, Miguel Luis, "Las cofradías religiosas y su dimensión social en la España del Antiguo Régimen", Cuadernos de Historia Moderna, 25 (2000), pp. 189-232. V.gr. se cita la adquisición de una capilla por parte del mayordomo de la cofradía de Ntra. Sra. de la Candelaria (p. 196), capilla que constaba de un Crucificado y una representación de las ánimas del purgatorio (p. 198)

2 Estas directrices conciliares pueden consultarse en línea; [consulta: 16 de abril de 2016], disponible: http://www.intratext.com/IXT/ESL0057/_P1G.HTM

3 Sobre el proceso de creación de la diócesis de Santander puede consultarse: GÓMEZ RODRÍGUEZ, Eduardo, "Una aproximación al estudio de la creación de la Diócesis de Santander", Cimas: Ciencia, Literatura y Pensamiento, 1 (2017), pp. 41-48. Igualmente, un estudio de la evolución histórica del territorio de la diócesis de Santander lo encontramos en ZUBIETA IRÚN, José Luis, Geografía histórica de la Diócesis de Santander, Santander, Universidad de Cantabria, 2008, en especial en el capítulo 3 (pp. 25-50) referido a la geografía eclesiástica durante la Edad Moderna.

4 BARRÓN GARCÍA, Aurelio Á., La época dorada de la platería burgalesa: 1400-1600, Salamanca, Junta de Castilla y León, Consejería de Educación y Cultura: Diputación Provincial de Burgos, 1998. El primer capítulo del primer volumen (pp. 17-21) de esta obra lleva por título el marco geográfico y en él se delimita territorialmente el arzobispado de Burgos en el siglo XVI. En la página 20 aparece un mapa muy clarificador al respecto. El mismo autor hace un nuevo estudio del espacio diocesano burgalés de la Edad Moderna en BARRÓN GARCÍA, Aurelio Á. y ESPEJO-SAAVEDRA, Rocío, La pintura mural en Valdeolea y su entorno, Santander, Fundación Marceli- 
diferenciar, dentro del espacio ocupado actualmente por Cantabria, dos zonas: las "Montañas Bajas" y las "Peñas de Castilla"

Desde el punto de vista temporal me centraré en la Edad Moderna, en especial en los siglos XVII y XVIII ${ }^{6}$, época coincidente desde el punto de vista artístico con el Barroco y caracterizada por una abun-

no Botín, 1998, pp. 21-33.

5 COFIÑO FERNÁNDEZ, Isabel, "Promoción artística en las Montañas Bajas del Arzobispado de Burgos: la arquitectura religiosa", Altamira, 58 (2001), p. 7. Se recoge en este artículo esta diferenciación del territorio perteneciente a la diócesis burgalesa:

Las "Montañas Bajas" englobarían todos los territorios cuyas aguas vierten al Mar Cantábrico.

"Peñas de Castilla" englobaría el territorio de Campoo.

La misma autora hace una descripción más pormenorizada de este territorio en la introducción de su libro COFIÑO FERNÁNDEZ, Isabel, Arquitectura religiosa en Cantabria (1685-1754), Santander, Universidad de Cantabria, 2004, pp. 15-19.

González Echegaray señala que en el siglo XVII el territorio de la actual Cantabria pertenecía a cuatro obispados distintos: “La parte más importante, que comprendía Campoo, Trasmiera y las demás parroquias orientales hasta los confines de Vizcaya, Pas y las Asturias de Santillana, estaba integrada en el arzobispado de Burgos y constituía un conjunto de unas 540 parroquias. El obispado de León integraba la mayor parte de Liébana, con un total de unas 65 parroquias. A la diócesis de Palencia pertenecía el valle de Polaciones y algunos enclaves de Liébana, con un total de 15 parroquias. El obispado de Oviedo tenía Tresviso y tres parroquias en Herrerías y Val de San Vicente (Bielva, Rábago y San Pedro de las Baheras)" citado en GONZÁLEZ ECHEGARAY, Joaquín, "Estructura eclesiástica y niveles de poder en la Cantabria del siglo XVII" en VV.AA., Población y sociedad en la España Cantábrica durante el siglo XVII, Santander, Institución Cultural de Cantabria, 1985, p. 13.

En 1660 Pellegrino Zuyer elaboró un mapa de las Montañas Bajas de Burgos que se reproduce en, CASADO SOTO, José Luis, Cantabria vista por los viajeros de los siglos XVI y XVII, Santander, Centro de Estudios Montañeses, 2000, pp.167-168.

6 MANTECÓN MOVELLÁN, Tomás A., Contrarreforma y religiosidad popular en Cantabria. Las cofradías religiosas, Santander, Universidad de Cantabria/Asamblea Regional de Cantabria, 1990, p. 43. Considera es autor que las cofradías, que empiezan a fundarse en el ámbito urbano a finales del siglo $\mathrm{XV}$, se expanden en el siglo $\mathrm{XVI}$ $\mathrm{y}$, sobre todo, es en los siglos XVII y XVIII cuando alcancen un pleno desarrollo y penetren hacia el mundo rural.

Es en estos siglos donde puede observarse un extraordinario incremento en el ingreso de las diferentes cofradías, como puede verse en los gráficos recogidos en MANTECÓN MOVELLÁN, Tomás A., "Cofradías religiosas y religiosidad popular en la Cantabria Moderna" en MARURI VILLANUEVA, Ramón (ed.), La Iglesia en Cantabria, Santander, Obispado de Santander, 2000, pp. 260-265. 
dante producción artística ${ }^{7}$ en Cantabria. Se trataría de un periodo en el que la principal preocupación por parte de las élites fue "cristianizar unas masas populares que lo estaban sólo superficial o débilmente $^{\prime \prime}{ }^{8}$ pues lo vigente en toda Europa, y por extensión en los territorios de la actual Cantabria, era una especie de sincretismo religioso. $\mathrm{Y}$ es precisamente en este proceso de "cristianización" donde adquiere una importancia especial el arte, como lo había tenido en el periodo medieval, que se convierte en un potente instrumento de aculturación ${ }^{9}$ siendo las cofradías religiosas una de las instituciones que patrocinen este desarrollo artístico ${ }^{10}$.

Pese a la imagen negativa que se pueda derivar de las opiniones que los obispos de Burgos y los visitadores por ellos enviados a esta zona transmitieron - la consideraban una zona excéntrica y mal comunicada, que gozaba de mala salud espiritual y con templos bastante deficientes ${ }^{11}-$ hemos de tener presente que "en clave religiosa se

7 GIL AGUIRRE, Elena, “Arte y patrocinio. La impronta de la clientela en el Barroco cántabro", Trasdós, 1 (1999), p. 63.

8 FONSECA MONTES, Josué, "La Contrarreforma en Cantabria”, en I Encuentro de Historia de Cantabria, Santander, Universidad de Cantabria/Gobierno de Cantabria, 1999, p. 838.

9 CAMPUZANO RUIZ, Enrique, Retablos de Cantabria, Santander, Caja Cantabria, 1989 , p. 62 señala que "el aspecto artístico ocupa un lugar primordial en la difusión de la teología emanada del Concilio de Trento, como elemento de propaganda y prestigio de la Iglesia romana". [...]"A través de las imágenes - catapultadas a la cumbre de la religión y fundamento de la fe de los fieles - se busca la relación directa con la divinidad, a través de la jerarquía eclesiástica".

10 "Los componentes básicos que incidieron en la expresión artística religiosa de las comunidades rurales cántabras durante los siglos del Barroco fueron, por un lado, las propias manifestaciones tradicionales, exteriorizadas particularmente desde las cofradías y los santuarios, y, por otro, la especial visión del clero, tanto secular como regular que intentaron modificar la mentalidad religiosa popular conforme a los criterios tridentinos"; POLO SÁNCHEZ, Julio J., "Arte y religiosidad en las “Montañas Bajas" del arzobispado de Burgos", Trasdós, 1 (1999), p. 89.

11 Sirva de ejemplo el informe que redactó el arzobispo Vela en el que dice "que en sola aquella parte del vasto territorio de su archidiócesis, había encontrado más pecados públicos que en todas las demás y que la presencia de un prelado era el único arbitrio para su remedio" citado en CASADO SOTO, José Luis, Cantabria vista por los viajeros de los siglos XVI y XVII, Santander, Centro de Estudios Montañeses, 2000, p. 291.

FONSECA MONTES, Josué, “La Contrarreforma en Cantabria”..., p. 851 recoge el 
interpretaban el nacer y el morir, la salud y la enfermedad, la bonanza y lo calamitoso, el trabajo y el descanso"12. Es esta omnipresencia de lo religioso lo que explica la prolífica creación artística de este periodo en todo el territorio peninsular ya que "la Iglesia española se adscribió sin límites al empleo de la imagen como medio de acercamiento y propagación de la fe... La imagen religiosa se entiende como instrumento de persuasión orientado a conmover y convencer al fiel y servir de exégesis de los misterios de la fe. En la crisis espiritual que planteó la confrontación Catolicismo-Protestantismo, la imagen religiosa se ofrecía, por sí misma, como una profesión de $\mathrm{Fe}^{\prime \prime 13}$.

\section{LA PROMOCIÓN ARTÍSTICA}

Parece evidente que la demanda de obras artísticas se incrementa en los siglos XVII y XVIII ${ }^{14}$ fruto de la recuperación económica que experimenta este territorio desde fines del siglo XVI y de las propias

siguiente extracto de la visita pastoral realizada entre 1706 y 1710 durante el pontificado del obispo Navarrete donde se dice que "los fieles que habitan dichas montañas Bajas están en grandísimos errores en materia de la ignorancia, porque no tienen quien les instruya y catequice en los misterios principales de nuestra Santa Fe Católica Apostólica Romana; viviendo como animales brutos, sin conocer que existe Dios más que por lo que oyen decir".

González Echegaray discrepa de estas valoraciones afirmando que se creó "un verdadero mito, el de una Cantabria pagana en pleno siglo XVII, lo que a todas luces no respondía a la realidad"; GONZÁLEZ ECHEGARAY, Joaquín, "Estructura eclesiástica y niveles de poder en la Cantabria del siglo XVII" ..., p. 32.

12 MARURI VILLANUEVA, Ramón, "Vida religiosa en la Cantabria del Antiguo Régimen", en MARURI VILLANUEVA, Ramón (ed.), La Iglesia en Cantabria, Santander, Obispado de Santander, 2000, p. 204.

13 NIETO ALCAIDE, Víctor y CHECA CREMADES, Fernando, El Renacimiento. Formación y crisis del modelo clásico, Madrid, Istmo, 1980, p. 338, obra citada en POLO SÁNCHEZ, Julio J. y SAZATORNIL RUIZ, Luis (ed.): Arte en Cantabria. Itinerarios, Santander, Aula de Etnografía: Universidad de Cantabria/Consejería de Educación y Juventud del Gobierno de Cantabria, 2001, p. 151.

14 Julio Polo señala que "el cambio del signo económico que comenzó a apreciarse en las primeras décadas del siglo XVII, unido a la influencia de los cánones tridentinos, manifestados a través de las constituciones sinodales y las visitas pastorales, relanzaron la contratación de obras, primeramente arquitectónicas y después mobiliares (retablos e imágenes aisladas, pinturas, orfebrería y ornamentos)"; POLO SÁNCHEZ, Julio J. “Arte y religiosidad..., p. 86. 
Constituciones Sinodales de Burgos ${ }^{15}$ que pretenden regular la creación artística y que no hacen más que adaptarse a las propias directrices emanadas del Concilio de Trento ${ }^{16}$ ya citadas donde se defiende el valor didáctico de las imágenes sagradas.

La financiación de las obras de arte, esto es, el patrocinio artístico, tuvo como principales puntales a:

Las familias que se enriquecen en el ámbito rural y/o personajes que lo hacen desempeñando altos cargos en la jerarquía eclesiástica, en la Corte o en sedes administrativas o militares que destinan parte de su nueva fortuna a la mejora del solar familiar o fabricación u ornamentación de su parroquia ${ }^{17}$ con diversos fines ${ }^{18}$.

15 Julio Polo recoge una transcripción de las mismas; POLO SÁNCHEZ, Julio J., La escultura romanista y contrarreformista en Cantabria (c. 1590-1660), Santander, Fundación Marcelino Botín, 1994, pp. 467-480. En concreto, en el libro III titulado De eclesiis aedificandis vel reparandis se recogen los siguientes capítulos:

Capítulo I: Que no se den a hazer las obras de las iglesias sin que tengan renta para ello, y que los officiales que las tomaren a hazer no se puedan llamar a engaño aunque le aya en más de la mytad del justo precio.

Capítulo II: Que las obras de las yglesias se den cada una al que fuere oficial de tal obra y que no la apueda traspassar a otro.

Capítulo III: Que ninguno edifique de nueuo monasterio, ni yglesia sin licencia del prelado. Capítulo IIII: Que las ermitas e yglesias que están en despoblado estén bien reparadas y tengan ornamentos necessarios.

Capítulo V: Pónese la forma y manera que se ha de tener para darse a hazer las obras de las yglesias.

16 "Enseñen con esmero los Obispos que por medio de las historias de nuestra redención, expresadas en pinturas y otras copias, se instruye y confirma el pueblo recordándole los artículos de la fe, y recapacitándole continuamente en ellos: además que se saca mucho fruto de todas las sagradas imágenes, no sólo porque recuerdan al pueblo los beneficios y dones que Cristo les ha concedido, sino también porque se exponen a los ojos de los fieles los saludables ejemplos de los santos, y los milagros que Dios ha obrado por ellos, con el fin de que den gracias a Dios por ellos, y arreglen su vida y costumbres a los ejemplos de los mismos santos; así como para que se exciten a adorar, y amar a Dios, y practicar la piedad"; Sesión XXV (del Concilio de Trento), Que es la IX y última celebrada en tiempo del sumo Pontífice Pío IV, principiada el día 3, y acabada en el 4 de diciembre de 1563. [Consulta: 15 de junio de 2017] disponible en http://www.intratext.com/x/es10057.htm

17 GIL AGUIRRE, Elena, "Arte y patrocinio..., p. 63

18 COFIÑO FERNÁNDEZ, Isabel, "Promoción artística en las Montañas Bajas..., pp. 15-16. Señala esta autora que lo que perseguían estos patrocinadores era "evidenciar ante sus convecinos el poder de quien las realizaba"; "deseo del promotor 
La piedad popular, a través de las disposiciones testamentarias, también contribuyó a enriquecer el patrimonio eclesiástico al tiempo que fomentaban la financiación y encargo de objetos artísticos ${ }^{19}$. En este apartado podemos incluir a los párrocos ${ }^{20}$, que pese a disponer, en general, de recursos muy limitados ${ }^{21}$, llegaron incluso a fundar alguna ermita.

Los cabildos catedralicios que aunque en el caso de Cantabria no se dio, sí que la pugna por la catedralidad entre Santillana del Mar y Santander contribuyó a que se acometieran importantes obras en ésta época ${ }^{22}$.

Las colegiatas y órdenes regulares, que gozaron de buena salud económica en los siglos XVII y XVIII lo que les permitió abandonar la sobriedad de sus obras iniciales a favor del arte Barroco cuyo lenguaje propagandístico sirvió a sus fines ${ }^{23}$.

de que esa obra se convirtiera en recuerdo de su figura y de su propio linaje"; "utilizar las construcciones como lugares de sepultura de sus fundadores y de los miembros de sus familias"; o "un fin puramente benéfico-docente".

19 GIL AGUIRRE, Elena, "Arte y patrocinio..., p. 65.

20 COFIÑO FERNÁNDEZ, Isabel, “Promoción artística en las Montañas Bajas..., p. 18.

21 Sobre el potencial económico del clero puede consultarse FONSECA MONTES, Josué, El clero en Cantabria en la Edad Moderna, Santander, Universidad de Cantabria, 1996, pp. 118-140. La opinión defendida por esta autor de un clero que se mueve en el límite de la subsistencia ("escasez generalizada de ingresos que el clero montañés poseía", p 140) es refutada por González Echegaray quien afirma que "en líneas generales la situación del bajo clero era lo que llamaríamos honesta económica y socialmente. En algunas zonas, como en Trasmiera, tales clérigos vivían particularmente bien y con una cierta holgura"; GONZÁLEZ ECHEGARAY, Joaquín, "Estructura eclesiástica y niveles de poder en la Cantabria del siglo XVII" ..., p. 23.

22 GIL AGUIRRE, Elena, "Arte y patrocinio..., p. 66. En esta época en la colegiata de Santander se construirá la sacristía y el coro, mientras que en Santillana del Mar se construirá la casa rectoral; ARAMBURU-ZABALA HIGUERA, Miguel Ángel, "De colegiata a catedral", capítulo correspondiente a la obra CASADO SOTO, José Luis, La Catedral de Santander. Patrimonio monumental, Santander, Fundación Marcelino Botín, 1997, pp. 129-163. Aquí se pueden seguir las evoluciones artísticas de la iglesia colegial de Santander con las modificaciones experimentadas en este periodo de los siglos XVII y XVIII.

23 COFIÑO FERNÁNDEZ, Isabel, “Promoción artística en las Montañas Bajas..., pp. 20-25. 
Las parroquias ${ }^{24}$, principales financiadoras de las obras al disponer de solvencia económica ${ }^{25}$ como consecuencia de un incremento de las rentas favorecido por la bonanza económica general experimentada en el siglo XVII' ${ }^{26}$.

Los concejos, de quienes dependía la construcción y mantenimiento de edificios y obras públicas así como las iniciativas para ampliar o construir nuevos templos, ermitas o retablos ${ }^{27}$.

A todos estos patrocinadores hemos de añadir a las cofradías quienes, fruto de sus preocupaciones por venerar advocaciones concretas a través de cultos y ceremonias, costearon edificios propios, capillas en las parroquias o conventos, imágenes de culto, retablos, $\ldots{ }^{28} \mathrm{al}$ tiempo que auxiliaron, voluntariamente $\mathrm{u}$ obligadas por el visitador, a las parroquias cuando éstas se embarcaban en proyectos para cuya realización los bienes de la fábrica no eran suficientes ${ }^{29}$.

\section{LAS COFRADÍAS RELIGIOSAS: ALGUNOS EJEMPLOS SIGNIFICATIVOS}

Las cofradías religiosas ${ }^{30}$ fueron, como se ha dicho en el apartado anterior, uno de los actores participantes en la promoción de obras

24 COFIÑO FERNÁNDEZ, Isabel, "Promoción artística en las Montañas Bajas..., p 26.

25 POLO SÁNCHEZ, Julio J., "Arte y religiosidad..., p. 86 alude a "la costumbre de encargar la realización de obras sin que la parroquia contase con los caudales suficientes".

26 En CASADO SOTO, José Luis, Cantabria en los siglos XVI y XVII. Historia General de Cantabria. Tomo V, Santander, Tantín, 1986, pp. 142-150, se alude a la "revolución del maíz" como responsable del incremento de las rentas. Se cita un memorial del año 1645 dirigido al rey Felipe IV contraria a la erección del Obispado de Santander que dice así: "y el medio que parece más forçoso para conseguir el fin que se pretende, viene a ser más duro, contrario y nocivo que quantos se han propuesto: oy las rentas que goza el Arzobispo de Peñas abaxo han crecido, desde ocho mil ducados que solían valer, hasta quinze, por la nueva cosecha que se ha introducido de maíz en aquella tierra".

27 GIL AGUIRRE, Elena, “Arte y patrocinio..., p. 67.

28 GIL AGUIRRE, Elena, “Arte y patrocinio..., p. 67. Véase también en COFIÑO FERNÁNDEZ, Isabel, “Promoción artística en las Montañas Bajas..., p 29.

29 POLO SÁNCHEZ, Julio J., "Arte y religiosidad..., p. 87.

30 Para el estudio de las cofradías religiosas se pueden consultar las siguientes publicaciones de Mantecón Movellán: 


\section{$\operatorname{artísticas~}^{31}$. Si bien tuvieron una escasa importancia en la iniciativa y}

MANTECÓN MOVELLÁN, Tomás A., "Cofradías religiosas y religiosidad popular en la Cantabria Moderna..., pp. 243-266. Se alude en este artículo al papel de las cofradías como instrumento que "supone colocar a la sociedad dentro de la Iglesia", "a la Iglesia dentro de la sociedad" y que permite "conocer el tipo de religiosidad que se impulsaba y practicaba por estas instituciones en la Edad Moderna"; pp. 243-244. Se trata también de la importancia de las cofradías en la reforma de las costumbres impulsada por la Iglesia post-tridentina; como "constructoras" de la moral individual (confesión-comunión-penitencia) y como agentes activos en la cultura.

MANTECÓN MOVELLÁN, Tomás A., "El papel social de las cofradías tridentinas en Cantabria. Siglos XVII al XIX", Altamira, 47 (1988), pp. 227-260. Aquí el autor señala que las cofradías "proponían la integración simbólica, no cuestionada, de la comunidad campesina bajo el signo de la fraternidad, con el objeto de cohesionar la feligresía, homogeneizar las devociones y asegurar la participación de la sociedad en la práctica religiosa"; pp. 228-229. Señala también que buscaban "la armonización, quietud y paz social"; p. 239. Así mismo afirma que las cofradías "ofrecieron la posibilidad de solucionar de forma colectiva y bajo el signo de la fraternidad, la conflictividad hacia dentro de las propias comunidades aldeanas; p. 259. En definitiva, se dibuja una función de las cofradías como un modelo de comunidad ideal, de auxilio mutuo, acorde con las propuestas tridentinas, a la vez que como niveladoras de las tensiones sociales. POLO SÁNCHEZ, Julio J., "Arte y religiosidad..., p. 92.

MANTECÓN MOVELLÁN, Tomás A., Contrarreforma y religiosidad popular en Cantabria... En esta obra, que contiene el trabajo de investigación del autor, se hace un estudio profundo del papel de las cofradías religiosas como instrumento aculturizador de la sociedad al servicio de los principios tridentinos. En esta obra se estudia no solo la vertiente religiosa de las cofradías, sino la social, su papel de canalizadoras de comportamientos sociales, de corrección ante posibles desviaciones y de ligazón de las comunidades.

31 Sobre qué significa la pertenencia a la cofradía y el sentido de disponer de patrimonio por parte de la misma seguimos a ARIAS DE SAAVEDRA ALÍAS, Inmaculada y LÓPEZ-GUADALUPE MUÑOZ, Miguel Luis, “Las cofradías religiosas..., p. 199 donde dicen que

"Suponía, en principio, la pertenencia a un cuerpo, legalizado por la aprobación eclesiástica y regido por unas normas de funcionamiento, contenidas en sus reglas; un cuerpo donde se dejaba oír su voz. De hecho, estas cofradías funcionaban de forma democrática. De entrada, renovaban sus cargos cada año. Los hermanos estaban obligados, e incluso lo hacían con orgullo, a ejercer los cargos de responsabilidad en la cofradía. Sí, se sentían orgullosos, como se comprueba por la defensa de los intereses de la hermandad, por la alusión a su antigüedad, por el respeto a quienes les precedieron, por el esfuerzo con que enriquecían el patrimonio de la cofradía, incluso con notables sacrificios económicos personales". [...] "Porque estaban orgullosos y defendían intereses corporativos, pretendían destacar entre los demás (otros feligreses, otros parroquianos, otros trabajadores). Rivalizaban, a nivel simbólico, en el boato y solemnidad de sus 
financiación de obras arquitectónicas ${ }^{32}$, ésta fue mayor en el fomento de obras escultóricas y retablísticas ${ }^{33}$. "Tras estas obras se ocultaba una intencionalidad básicamente religiosa, encaminada a glorificar la imagen de devoción propia de cada cofradía, a pesar de que ello conllevase un cierto espíritu propagandístico en el sentido de que muchas de las advocaciones que daban nombre a estas cofradías habían sido puestas en tela de juicio por los sectores protestantes, de modo que al financiar obras destinadas a ellas se cumplía el doble cometido de darles culto y de impulsar la devoción de esas advocaciones" ${ }^{\prime 34}$.

Nos detendremos en el estudio de algunos ejemplos de la creación artística en la que participaron las principales cofradías religiosas ${ }^{35} \mathrm{de}$ la Cantabria de la Edad Moderna.

\section{1. Cofradía de la Vera Cruz}

En el Valle de Meruelo, en la parroquia de San Mamés tuvo presencia esta cofradía como lo atestigua el documento que recoge la orden para

actos de culto, rivalizaban en la ostentación y participación en las procesiones, reclamando cuando era necesario lugares destacados dentro y fuera del templo". Para el caso concreto de Cantabria es de interés el artículo de FONSECA MONTES, Josué, "Las cofradías en Cantabria: elementos para la comprensión de una estructura socio-religiosa significativa en los siglos XVI-XVIII", Espacio, Tiempo y Forma, Serie IV, Historia Moderna, 20 (2007), pp. 43-71. El autor hace una clasificación entre cofradías de raíz popular y aquellas que son promovidas y controladas por las élites religiosas. De igual forma defiende que el territorio de la actual Cantabria no difirió mucho ni en número ni en cronología en cuanto a la creación de las cofradías.

32 COFIÑO FERNÁNDEZ, Isabel, "Promoción artística en las Montañas Bajas..., p. 29. Dice la autora: "el análisis de las empresas arquitectónicas sufragadas por las cofradías durante nuestro periodo de estudio demuestra que tuvieron una escasa importancia cualitativa y cuantitativamente". Cita los casos de la edificación de capillas del Rosario en las iglesias de Bárcena Mayor, Bostronizo y Arenas de Iguña.

33 POLO SÁNCHEZ, Julio J., “Arte y religiosidad..., p. 92. Dice así: “La promoción artística por parte de las cofradías cántabras es un fenómeno que corresponde fundamentalmente al siglo XVIII y que se concreta en el encargo de la imagen del titular o de su retablo en la iglesia parroquial"

34 COFIÑO FERNÁNDEZ, Isabel, “Promoción artística en las Montañas Bajas..., pp. 30-31.

35 Serán las cofradías de la Vera Cruz, El Rosario y las Ánimas las tres más numerosas que aparezcan en Cantabria. Un estudio cuantitativo de las mismas puede consultarse en FONSECA MONTES, Josué, “Las cofradías religiosas..., p. 46 
que se hiciese un Crucificado como el existente en la parroquia de San Miguel $^{36}$ para el altar que dicha Cofradía tenía en la iglesia parroquial.

Por su parte, en la parroquia de San Miguel de Meruelo están presentes las Cofradías del Santísimo Sacramento y la de la Santa Vera Cruz, ambas con una actividad relacionada con la celebración de misas, sufragios, vigilias, procesiones, bendiciones y responsos ${ }^{37}$. Desde el punto de vista artístico hay que destacar el retablo de la Vera Cruz ${ }^{38}$

36 Del año 1653 data el siguiente documento recogido en GONZÁLEZ ECHEGARAY, María del Carmen, Documentos para la historia del arte en Cantabria: (escultores, entalladores y pintores de los siglos XVI al XVIII), Tomo II, Santander, Diputación provincial de Santander, 1973, p. 25:

“Otrosí por cuanto por el testamento con que murió el Dr. Juan Alonso del Mazo, beneficiado que fue de esta iglesia, dejó algunas obras pías, como fue el que se hiciese una imagen de un crucificado de piedra labrada, conforme al que estaba en el Calvario de la Parroquia de San Miguel, para el de la Vera Cruz de la Parroquia. Y asimismo se hiciese una campana en la Ermita [...] y caso que la hechura del Santo Cristo no sea necesaria para el Calvario de la Vera Cruz, dicho Arcipreste ajustará, informándose de personas que lo entiendan, lo que pueda valer, y se ponga declaración para que se le dé y pague al Mayordomo de la Cofradía de la Santa Vera Cruz, para ayuda del gasto... de dicho Calvario, y lo demás cumpla y ejecute".

37 Archivo Histórico Provincial de Cantabria (en adelante, AHPC), legajo 5039. Año de 1704 citado en ESCALLADA GONZÁLEZ, Luis, Historia del Valle de Meruelo. Siete Villas en el Antiguo Régimen. Fuentes documentales, Santander, Ayuntamiento de Meruelo, 1998, pp. 214-215. Como ejemplo de algunas de las prácticas aquí recogidas sirva la trascripción de los dos párrafos siguientes:

"pagamos todos los años a los Beneficiados de dicha Iglesia que ha sido y son, veinte y dos Reales de vellón por el trabajo de las procesiones de entre año, en cada uno, y por la bendición de términos, frutos y ganados, y echar por los sembrados y tierras de nuestro distrito el agua que llamamos comúnmente de San Gregorio - con procesión-".

"han de ser obligados a ir en procesión con los vecinos en cada un año el día doce de Mayo a la ermita de la Magdalena, el segundo día de Pascua de Resurrección a la de Santa Ana, y el día dos de Junio a la de Nra. Sra. de los Remedios; y el día de Señor San Julián, siete de enero, a la bendición de los ganados por la mañana a los puestos de cada cuarto señalados".

38 POLO SÁNCHEZ, Julio J. (ed.), Catálogo del patrimonio cultural de Cantabria. Tomo II: La Merindad de Trasmiera: Juntas de Ribamontan, Siete Villas y Voto, Villas de Escalante y Santoña, Santander, Consejería de Cultura y Deporte del Gobierno de Cantabria, 2001, pp. 274-275. Se describe aquí el retablo de la siguiente manera: "Este retablo es de un solo cuerpo de orden corintio y ático rematado en frontón curvo, enmarcado por frontón curvo partido avolutado y con remates apiramidados. En el pedestal tiene unas pinturas sobre tela con las escenas del Prendimiento, Vía Crucis, Ecce 
que se encuentra en el lado de la Epístola de la iglesia parroquial y cuya construcción es anterior al año 1652 y que fue dorado en 1681 como consta en una inscripción en la base del pedestal: "Esta obra DORARON POR SU CUENTA LOS COFRADES DE VERA CRUZ DE ESTA PARROQUIA 1681 Y LA DORO Y PINTO MAT...".

En la iglesia parroquial de Limpias existe una capilla y un retablo ${ }^{39}$ pertenecientes a la Cofradía de la Vera Cruz, cofradía que data del siglo XVI. Llama la atención su similitud con el conservado en la iglesia de San Miguel de Meruelo lo que, unido a su similar cronología, nos hace pensar que se adaptaban a las corrientes artísticas del momento.

En Rasines hay constancia también de que la cofradía de la Vera Cruz contrató la realización de un retablo colateral para el altar de San Juan que se ajusta a los modelos vistos con anterioridad ${ }^{40}$.

Homo, Crucifixión, Flagelación y Oración en el Huerto. En el cuerpo principal se sitúa una imagen de bulto de Cristo Crucificado de tradición romanista, colocado sobre un fondo pintado, actualmente muy desfigurado, con María y San Juan. Los dos bustos de San Emeterio y San Celedonio datan de fines del siglo XVIII y fueron pintados y dorados en 1801. En el ático se encuentra un Cristo Resucitado".

$39 \mathrm{Su}$ descripción la podemos encontrar en ARAMBURU-ZABALA HIGUERA, Miguel Ángel (dir.), Catálogo Monumental de las Cuencas del Asón y Agüera. Tomo II: Municipios de Limpias, Ramales de la Victoria, Rasines, Ruesga y Villaverde de Trucíos, Santander, Ed. Asociación grupo acción local Asón-Agüera, 2001, p. 375. Dice así: "El retablo data de la primera mitad del siglo XVII y consta de banco con los relieves de San Andrés, La Virgen María, San Juan y un Apóstol, y las pinturas de la Santa Cena, Flagelación y Lavatorio; un cuerpo de orden corintio con columnas de fuste entorcahdo y frontón curvo avllutado, teniendo la imagen central dedicada a Cristo Crucificados (en relación con María y San Juan del banco) sobre el fondo de Jerusalén pintado, y sobre su cabeza, pintados el Padre y el Espíritu Santo, y la pintura de San Sebastián en el frontón. La imagen de Cristo es de buena calidad, con tres clavos, paño de pureza abierto y corona labrada. Destaca en el retablo la excelente policromía, así como la pintura de Jerusalén".

40 AHPC, legajo 3545. Año de 1707 recogido por GONZÁLEZ ECHEGARAY, María del Carmen, Documentos para la historia del arte en Cantabria..., Tomo II, pp. 114-118. Recogemos a continuación sólo dos de las condiciones del retablo:

"Primeramente es condición que ha de llevar la planta, de seis columnas salomónicas, las cuatro de afuera paralelas y las otras dos fondeadas adentro, vestidas de parra con sus racimos correspondientes a las dos que están hechas para dicho colateral". "Item. es condición que los intercolumnios hayan de llevar la guarnición de tarjetillas enredadas de cinco dedos de ancho, acodillados, y en sus codillos sus tamanillos con sus tarjetas que busquen y cubran el alto del arquitrabe, y en los dichos intercolumnios, ha de llevar sus dos historias: Cristo con la Cruz, acuestas al lado de la epístola, y al otro lado el Descendimiento, y 
En Santander ésta cofradía encargó la ejecución de la imagen de un Ecce Homo ${ }^{41}$ en el año 1626 a Juan de Palazuelos por 154 reales.

También comisionó y costeó un retablo ${ }^{42}$ para la capilla de la Santa Cruz que tiene en el lado del Evangelio de la ermita de Nuestra Señora de Valencia en Vioño de Piélagos, cuyo montante ascendió a 1040 reales. Una vez más, la tipología exigida es similar a la ya vista para los casos de San Miguel de Meruelo, Limpias o Rasines.

en el medio Cristo crucificado, y arriba Nuestra Señora de la Soledad, y sobre las columnas de afuera, encima de su pedestal, dos ángeles, el uno con los clavos y la corona, y el otro con las tenazas y martillo, y esta condición queda afuera de su obligación de Colateral a cuenta de la iglesia".

41 AHPC, legajo 24. Año de 1626 recogido por GONZÁLEZ ECHEGARAY, María del Carmen, Documentos para la historia del arte en Cantabria: (escultores, entalladores y pintores de los siglos XVI al XVIII), Tomo I, Santander, Diputación provincial de Santander, 1971, p. 32: "ha de hacer una figura de Ecce Homo de madera de nogal, entero, acabado por delante y por detrás, en toda perfección y a satisfacción de los dichos Mayordomos, de vara y media de alto, con su peana, con su cruz, la que fuere necesaria y toda ella hueca y de cuarta de ancho o menos, conforme vieren que conviene, lo cual dará hecho para fin del mes de Octubre primero que viene de este año".

42 AAHPC, legajo 586. Año de 1664 recogido en GONZÁLEZ ECHEGARAY, María del Carmen, Documentos para la historia del arte en Cantabria..., Tomo I, pp. 45-46. En él se recogen las condiciones del retablo, que son:

"La primera, que el dicho Retablo se ha de hacer de madera seca, de nogal limpio, ybien cerrado, acomodando el roble (sic) a la vista, exceptuando los respaldos, que irán de castaño, y todo como lo demuestra la traza conque se hizo el dicho remate, que está firmada del propio escribano, en todo lo que no es en contrario e las dichas condiciones.

Item es condición, que el pedestal de dicha obra, vaya conforme lo muestra la traza, y con la misma talla, y las columnas han de ser estriadas, culubriadas como lo muestra la traza, con sus capiteles corintios, con sus alcachofas, y las pilastras han de llevar sus zócalos, collarinos y cimacios y el cornisamiento, conforme lo muestra la traza, con su friso que corre de cabo a cabo.

Item. es condición, que el nicho alto, ha de ser cuadrado, quedando con su recuadro, y en él ha de llevar una Cruz con su peana, y ha de llevar revoltones y arbotantes, con sus pirámides, como lo muestra la traza.

Item. es condición que las columnas, ha de ir culubriadas, con sus machuelos, a macho y hembra y mdias cañas, y las cajas han de llevar de fondo pie y medio, sin lo que las columnas vuelen, y en la caja principal, un Santo Cristo, atado a la columna, con dos sayones haciendo la acción de acostarle, todos tres de bulto y buena madera, y que proporcionalmente ocupen la caja." 


\section{2. Cofradía de Nuestra Señora del Rosario}

En Meruelo nos encontramos con la existencia de las Cofradías del Rosario y del Santísimo Sacramento que se hallan entre las más antiguas de la Edad Moderna. Además, en la iglesia de San Mamés nos encontramos con la presencia de la Cofradía de Nuestra Señora de las Candelas, junto a las dos citadas ${ }^{43}$. Todas ellas realizaban también procesiones por lo que, pese a no tener constancia documental, suponemos que disponían de ornamentos litúrgicos para su realización como estandartes, pendones, cruces procesionales, luminarias,... Sí que consta que por parte del mayordomo de la Cofradía de Nuestra Señora del Rosario, Nicolás Negrete y Noval, se encarga la realización de unas andas y figura de Nuestra Señora del Rosario ${ }^{44}$, donde además es perceptible la rivalidad existente con la cofradía homónima del pueblo vecino de Castillo ${ }^{45}$, cuyas andas se quieren superar.

43 AHPC, legajo 4950. Año de 1650 citado en ESCALLADA GONZÁLEZ, Luis, Historia del Valle de Meruelo..., p. 212.

44 AHPC, legajo 4886. Año de 1624 recogido por GONZÁLEZ ECHEGARAY, María del Carmen, Documentos para la historia del arte en Cantabria..., Tomo II, p. 31. En este documento se recogen las condiciones del encargo y que son:

"Primeramente es condición que la figura sea de buena madera, seca y limpia, y de la misma traza y costa y alto que la que Juan de Pobes hizo para Castillo, y la corona ha de ser de plata porque la tiene hecha la cofradía para la figura y niño, y se entiende que debajo del serafín haya un testero de dos dedos de alto para que se le goce mejor la figura.

Es condición que las andas sean de madera de nogal todas, seca y limpia de la mesma costa que las de Juan de los Corrales hizo para el lugar de Castillo y del mesmo ancho y tres dedos más altas en todo, y el pedestal más bajo, vaya holgada y a lo más dos dedos, todas bien acabadas y perfeccionadas de la mesma costa y molduras que está dicho. [...].

Es condición que las andas han de tener tres dedos de alto más que las de Castillo, y han de tener todas las molduras que tienen las de Castillo y han de estar tan acabadas en toda perfección, ansí andas como imagen a vista de dicho oficiales, y por cualquier cosa que faltare quede obligado el dicho Maestro de recibirlas y volver el dinero que pareciere haber recibido, y el mayordomo desde el día de la declaración le pueda ejecutar y pueda dar a hacer dichas andas a otra persona, sin incurrir en pena alguna".

45 POLO SÁNCHEZ, Julio J. (ed.), Catálogo del patrimonio cultural de Cantabria..., Tomo II..., pp. 179-180. Se recoge aquí que

“en 1636 se contrató con Pedro Saiz de la Casanueva Merecilla la construcción de la capilla de Nuestra Señora del Rosario, propiedad de la cofradía del mismo nombre" [...] "Esta capilla contuvo un retablo, cuyo dorado se contrató en 1655 
En la iglesia parroquial de Arnuero, la cofradía del Rosario dispuso de capilla propia en el lado del Evangelio, con un retablo ${ }^{46}$ realizado entre 1650 y 1660, y dorado en 1692 por cuenta de dicha cofradía.

Disponemos, asimismo, del documento por el que la cofradía de Nuestra Señora del Rosario de Requejo solicita al arzobispo de Burgos, don Juan de Isla, permiso para el dorado de un retablo que posee en la iglesia parroquial ${ }^{47}$.

con el dorador Francisco de Somarraba. Dicho retablo debió de incluir en su interior una imagen más antigua que la propia capilla, que antes de 1624 había realizado Juan de Pobes y que le serviría de modelo para otra que efectuó entonces en la iglesia de San Mamés de Meruelo".

46 POLO SÁNCHEZ, Julio J. (ed.), Catálogo del patrimonio cultural de Cantabria..., Tomo II..., p. 172. Está basada esta cronología en "el empleo de columnas de fuste estriado en el cuerpo y pilastras ganchudas en el ático, unido al desarrollo ornamental de festones, tarjetas en las enjutas y aletones avolutados, de amplio volumen".

"En 1692 se redactaron las condiciones para el dorado de este retablo, cuyo contrato recayó en el maestro dorador local Luis de Foncueba, quien se comprometió a realizarlo por 1350 reales que serían pagados por la cofradía del Rosario, propietaria de la capilla".

47 AHPC, legajo 3928. Año de 1683 recogido por GONZÁLEZ ECHEGARAY, María del Carmen, Documentos para la historia del arte en Cantabria..., Tomo II. p., 83. El documento dice así:

“Nos los provisores en todo el Arzobispado de Burgos, por su Ilustrísima don Juan de Isla, Arzobispo del Arzobispado. Por cuanto ante nos se presentó la petición siguiente: Juan $\mathrm{R}^{\mathrm{o}}$ de Ubierna, en nombre de los mayordomos y oficiales de la Cofradía e Nuestra Señora del Rosario sita en la Iglesia parroquial del lugar de Requejo, como mejor hay a lugar parezco ante Vm. y digo que mis partes desean dorar un Retablo que tienen muy bueno, en que está la dicha imagen para su mayor adorno y decencia, cuyo coste están informados llegará a mil y quinientos reales de vellón poco más o menos, cuya cantidad y más tienen para este efecto además de cantidad de censos que tiene dicha cofradía a su favor y otras cosas, para lo cual y que puedan hacer dicha obra, pido y suplico a Vm. se sirva mandarles despache licencia $\mathrm{n}$ forma informándose en caso necesario de lo referido de la persona que sea servido, que así es justicia.

$Y$ en vista de dicha petición mandaos que los curas y beneficiados informasen cerca de lo en ella contenido, y habiéndolo hecho y presentado ante nos, en su vista, por la presente partimos y damos licencia a los dichos mayordomos para que puedan dar a dorar dicho Retablo con que su coste no exceda de dos mil reales concertándose para ello con el Maestro o Maestros que con más comodidad lo hicieren, otorgando en razón de ello las escrituras necesarias que para ello y lo anejo y dependiente, le damos licencia en toda forma, en Burgos a trece de marzo de mil y seiscientos y ochenta años". 
En la zona de los Carabeos ${ }^{48}$, es de señalar también la Cofradía del Santísimo Rosario de Arroyal fundada en 1666 y una de las más prolijas en la adquisición y generación de patrimonio artístico. En 1756 el párroco había encargado una imagen de Nuestra Señora del Rosario cuyo coste ascendió a 800 reales $^{49}$ a la que se dotó de alhajas y objetos de culto adquiridos durante el siglo XVIII ${ }^{50}$.

48 Hemos de precisar que todo este territorio ha pertenecido a la archidiócesis de Burgos hasta el año 1954 en que pasa a depender de la diócesis de Santander. Lo incluimos en el presente trabajo porque hasta la creación de la Diócesis de Santander en 1754, la inmensa mayoría del territorio de la actual Cantabria dependía eclesiásticamente de Burgos.

49 En las cuentas de la cofradía aparece la siguiente referencia: “La Ymagen de madera de nogal, el Niño Dios que tiene en su mano izquierda, la peana de dicha Ymagen de nuestra señora del Rosario, la encarnación, estofo y dorado, luceado y ojos de cristal esmaltados que tienen dicho Niño, Ymagen y uno d elos tres seraphines que estan unidos a la dicha peana y Ymagen en un globo de nuves... 800 rs".

"Vestido de casaca y ropa interior de dicha Ymagen que está ya colocada en su trono y retablo de la parrochia de este varrio de Arroyal, donde es patrona... $100 \mathrm{rs}^{\prime \prime}$.

"Vestido del Niño... 80 rs".

Todo ello aparece recogido en los libros 3096 y 3097 del Archivo Histórico Diocesano de Santander (en adelante, AHDS) referentes a la Cofradía del Ssmo. Rosario de Arroyal que aparecen citados en la obra de RODRÍGUEZ FERNÁNDEZ, Agustín, Los Carabeos. Historia, economía y sociedad en un concejo rural de la Merindad de Campoo, Santander, Centro de Estudios Montañeses/Institución Cultural de Cantabria, 1979, pp. 152 y 153.

50 RODRÍGUEZ FERNÁNDEZ, Agustín, Los Carabeos. Historia, economía y sociedad..., p. 153.

AÑo 1757 "De la hechura de la corona para la Ymagen nueva" 55 rs.

AÑo 1758 "Potencias de plata, que dicho mayordomo encargó en Burgos, las ha traído y están puestas en la cabea de el Niño Dios que tiene la Ymagen del Rosario"

AÑo 1764

"Engarce del Rosario de palta de Nuestra Señora"

17 rs.

AÑo 1765

Una cortina "para nuestra Señora con su galón y puntilla 94 rs. de plata para adorno y dos cornucopias de metal"

AÑo 1772

Una corona para "nuestra Señora la Antigua que se lleva en las procesiones del Rosario"

"Dos arañas, a quatro luces cada una, son de plata, están en custodia y no se han puesto por no haber limosnas para los yerros que son necesarios para colgarlas"

AÑo 1774 Hechura de los yerros para las arañas

842 rs., 24 mrs.

103 rs. 
En el año 1764 adquirió esta Cofradía un estandarte con la imagen de la Virgen ${ }^{51}$ por 408 reales.

En la iglesia de San Pedro de Limpias nos encontramos también con una capilla y un retablo pertenecientes a la Cofradía de Nuestra Señora del Rosario. El retablo ${ }^{52}$ fue costeado por la propia cofradía con la ayuda de don Francisco de Angulo. Fue construido entre los años 1752 y 1754 por el santoñés Francisco de la Piedra, y fue dorado en 1756 por Fernando Antonio de Fontagud.

En Valmaseda la cofradía encargó la realización de un retablo dedicado a la Virgen del Rosario para la capilla que posee en la iglesia parroquial ${ }^{53}$.

AÑo 1783 "Un pendón de veinte y dos varas y media de damasco 881 rs.
blanco, con sus cordones cruz y bara, dorada y cha-
rolada"

AÑo 1791 Una mesa de altar

316 rs., 8 mrs.

51 La descripción del mismo aparece recogida en RODRÍGUEZ FERNÁNDEZ, Agustín, Los Carabeos. Historia, economía y sociedad..., p. 152, donde dice “... y es estampa de lienzo pintada en él Nuestra Señora del Rosario, Santo Domingo y Santa Catalina de Sena, tres cabecitas de Angeles, nuves (sic) correspondientes, y más damasco, flecos, cintas, cordones con sus orlas, palo de pie y travieso dados de encarnación, Cruz y remates de metal, y el letrero que tiene dicha estampa notando al Ylustrísimo que concedió ochenta días de Indulgencia".

52 ARAMBURU-ZABALA HIGUERA, Miguel Ángel (dir.), Catálogo Monumental de las Cuencas del Asón y Agüera..., p. 374. Se describe el retablo así: "de planta mixtilínea, consta de banco, un cuerpo con tres calles y ático, teniendo por soportes columnas corintias de fuste estriado con rocallas, en la calle central con el tercio inferior decorado, y en el ático empleando machones con colgantes. Es una obra de buena calidad y estilo rococó. En el lado del Evangelio se sitúa la imagen de San Ramón Nonato; en el lado de la Epístola San Ignacio de Loyola, y en el ático Santo Domingo. Pero el retablo conserva una imagen de muy alta calidad, la de Nuestra Señora del Rosario, obra atribuida a Luis Salvador Carmona".

53 AHPC, Legajo 1606. Año de 1637. Recogido por GONZÁLEZ ECHEGARAY, María del Carmen, Documentos para la historia del arte en Cantabria..., Tomo II, pp. 35-36. “otorgamos y decidimos que por cuanto en el dicho Bernardo de Lombera se remató la obra de Arquitectura y escultura del Retablo de la Cofradía de Nuestra Señora del Rosario de la villa de Valmaseda, en doscientos ducados, los cuales se han de pagar por tercios; el primero ahora, de contado para comenzar y limpiar la madera para dicho Retablo, y la otra tercia parte para en estando hecha la mitad de la dicha obra, y el último para estando asentado el dicho Retablo en el sitio a donde se ha de asentar, y nos obligamos de dar hecho y acabado el dicho retablo según la traza y condiciones del remate en toda satisfacción, puesto en el altar y sitio de la iglesia a 
Igual circunstancia es la que vive la Cofradía de la Virgen Santísima del Rosario de Peñacastillo, la cual encarga un retablo para el altar colateral que posee en el lado del Evangelio de la iglesia de San Lorenzo ${ }^{54}$.

\section{3. Otras cofradías}

\section{Cofradía de San Martín}

En Laredo, nos encontramos con una de las pocas participaciones de las Cofradías religiosas en obras arquitectónicas. Se trataría de la reedificación del coro y tejado de la ermita de Santa Catalina realizada por la cofradía de San Martín en el año $1655^{55}$.

\section{Cofradía del Carmen}

Miembros de la cofradía del Carmen participarán en la ampliación de la ermita dedicada a esta advocación mariana en San Martín de Toranzo, si bien el dinero procede de indianos, ellos son quienes dirigen las obras ${ }^{56}$.

donde ha de estar en la villa de Valmaseda a nuestra costa y riesgo, dentro de nueve meses que corren desde el día de la fecha de esta escritura".

54 AHPC, Legajo 46. Folio 43. Año de 1653. Recogido por GONZÁLEZ ECHEGARAY, María del Carmen, Documentos para la historia del arte en Cantabria..., Tomo II, pp. 48-50, "dijeron que la dicha cofradía y cofrades de ella, han dado orden en su junta y capítulo al dicho mayordomo, con el dicho Maestro Ensamblador de dicha Arquitectura, se haya de hacer un Retablo para la dicha Imagen en su altar y a su medida del, con el segundo cuerpo de arriba, el Ángel de la Guarda, conforme a la traza y condiciones que se han ajustado con la dicha Cofradía [...] con declaración que las cuatro columnas principales se han de dorar con tercios de talla, y la fábrica ha de ser de nogal, seca y bien acondicionada, y añadiendo el Maestro conforme a su arte, que entre a más de lo que muestra la traza y la dicha obra y retablo el dicho Maestro como pareciese ser conveniente y va referido, la dará obrada y acabada, para el día de Nuestra Señora de Septiembre de este presente año, asentada en dicho altar".

55 COFIÑO FERNÁNDEZ, Isabel y MAZARRASA MOWINCKEL, Karen, Ermitas, capillas y santuarios de Cantabria, Santander, Colegio Oficial de Aparejadores y Arquitectos Técnicos de Cantabria, 2006, p. 86.

56 COFIÑO FERNÁNDEZ, Isabel y MAZARRASA MOWINCKEL, Karen, Ermitas, capillas y santuarios..., p. 149. Dicen estas autoras que en la construcción de dicha ermita "jugaron un importante papel los donativos de la familia Calderón de la Barca y Santibáñez, uno de cuyos miembros, don Ángel Calderón, remitió en el primer 
También fueron cofradías las que participaron en la reedificación de la ermita del Carmen de Castillo Pedroso finalizada en el año $1764^{57}$.

\section{Cofradía de San Crispín y San Crispiano}

En la iglesia parroquial de Santa María de Novales se manda construir por esta cofradía un retablo para sus santos titulares que al parecer no se concluyó en tiempo y forma ${ }^{58}$.

\section{Cofradía de San Sebastián y San Fabián}

Destaca en la zona de los Carabeos la Cofradía de San Sebastián y San Fabián ${ }^{59}$ fundada en 1521 en la iglesia parroquial de San Andrés. En el año 1620 se modifica la primitiva regla de la Cofradía y en la misma

tercio del siglo XVIII 568 pesos desde Indias, destinados a la "reedificación de la hermita de nuestra señora del Carmen y demas que necesitare para su adorno y decencia"'". Con este dinero se llevó a cabo "la fabrica de la capilla Mayor, Camarin y sacristía de dicha hermita y... las bovedas de toda la nave". Es decir, más que una reedificación se hizo una ampliación de la misma. La documentación en, AHDS, Libro de la Cofradía de Ntra. Sra. del Carmen. Sin Signatura, folios 30, 50. Referencia tomada de COFIÑO FERNÁNDEZ, Isabel, "Promoción artística en las Montañas Bajas..., p. 30.

57 COFIÑO FERNÁNDEZ, Isabel y MAZARRASA MOWINCKEL, Karen, Ermitas, capillas y santuarios..., p. 148. En torno a 1753 se declaraba que "la ermita aún no estaba totalmente concluida y que se hacía preciso que los mayordomos, cofrades y demás interesados en ella contribuyesen con lo necesario para poner fin a su edificación"; AHDS, Libro de la Cofradía del Carmen. 4588, fols. 38v., 39v., 40, 41r., 46r., 61r., 89v., 90v., 91r., 95v. Referencias tomadas de COFIÑO FERNÁNDEZ, Isabel, "Promoción artística en las Montañas Bajas..., p. 30 y 52.

58 GONZÁLEZ ECHEGARAY, María del Carmen, Documentos para la historia del arte en Cantabria..., Tomo II, pp. 113-114 cita procedente del libro de la Cofradía de los gloriosos Mártires San Crispín y San Crisipiano, sita en la Parroquial de Santa María, del lugar de Novales, años de 1705, lo siguiente: "da en data ochenta y tres reales y medio que se dieron a Dionisio de Pumera, escultor por las imágenes que se pusieron de nuevo en dicho retablo, que aunque se ajustaron a ciento treinta, sólo se pasa dicha cantidad por no se haber entregado lo demás ".

59 Como ocurre en la práctica totalidad de las Cofradías los objetivos de esta eran "la aplicación de beneficios espirituales - misas, rosarios,...- por las almas de los hermanos cofrades, vivos o difuntos. Su distintivo fue un manto de terciopelo negro con flecos de oro y cuatro saetas de madera policromada, símbolo del martirio del santo patrono" citado en RODRÍGUEZ FERNÁNDEZ, Agustín, Los Carabeos. Historia, economía y sociedad..., p. 149. 
podemos rastrear el patrimonio artístico que poseía y que se concretaba en una imagen de San Sebastián y el altar que la albergaba ${ }^{60}$.

En Hoznayo también existió un altar dedicado a San Sebastián financiado por la cofradía allí existente de dicha advocación ${ }^{61}$.

\section{Conclusiones}

El presente artículo, tal y como indica su título, no es más que una aproximación al papel que jugaron las cofradías en el patrocinio del patrimonio artístico religioso durante la Edad Moderna y, en concreto, a raíz del concilio de Trento en el territorio de la actual Cantabria.

Tras contextualizar la religiosidad de este espacio en el marco de los cambios surgidos a partir de las nuevas directrices emanadas del Concilio de Trento, hemos citado el papel que tuvieron en algunas

60 “Otrosí hordenamos y mandamos que, abiendo menester algunos reparos el Santo y su ymagen para en su altar, se le dé lo nezesario para el dicho reparo, a boluntad y albedrío de los señores confrades, ansí clérigos como legos, porque el Santo esté con mucha dezencia".

"Otrosí hordenamos y mandamos que los mayordomos, juntos con el Abad y alcaldes de la dicha Confradía, en cada un año, saquen y nombren dos mayordomos y un muñidor, y quel tal muñidor tenga cargo de ser merino, y que los tales mayordomos y merino o muñidor sean obligados de tener el dicho ofizio un año, so pena de que el que no quisiere azetar el dicho oficio pague de pena mil y quinientos marabedís y éstos se gasten (al) albedrío del Abad y mayordomos para reparos del altar e ymagen del señor San Sebastián y sus lumbres y luminarias".

“Otrosí hordenamos y mandamos que, si los mayordomos y Abad y demás confrades quisieren mober la ymagen de señor San Sebastián a otra Iglesia, lo puedan hacer libremente y llebar todos los reparos que estubieren en el dicho altar, los que fueren de la dicha Confradía, y esto con mucho concierto; y si todos los confrades no binieren en ello benga la mayor parte de ellos para que lo puedan hacer libremente a boluntad de la mayor parte".

Estas reglas aparecen recogidas en AHDS, libro 3122 referente a la Cofradía de San Sebastián y San Fabián, años 1620-1765; RODRÍGUEZ FERNÁNDEZ, Agustín, Los Carabeos. Historia, economía y sociedad..., pp. 169-178.

61 POLO SÁNCHEZ, Julio J. (ed.), Catálogo del patrimonio cultural de Cantabria. Tomo I: La Merindad de Trasmiera: Juntas de Cudeyo y Cesto, Santander, Consejería de Cultura y Deporte del Gobierno de Cantabria, 2000, p. 473. “En la nave del Evangelio existió un altar bajo arcosolio que alojó un retablo dedicado a San Sebastián. Por iniciativa d ela cofradía bajo la misma advocación, en 1626 se contrató con Domingo Marañón la pintura y dorado de las figuras de dicho santo, así como las de San Fabián y San Francisco. Esta pieza retablística desapareció". 
localidades de Cantabria las cofradías religiosas como patrocinadoras de diferentes obras de arte. Se han buscado ejemplos de zonas alejadas entre sí para comprobar si comparten características comunes (encargos, devociones,...) pudiendo corroborar que, independientemente del lugar en el que se encuentren, las cofradías tienen unos mismos objetivos y actúan de manera similar. Por ejemplo, la actuación que con más frecuencia se repite en las fuentes consultadas es el encargo de la construcción de altares y de imágenes relacionadas con la titularidad de la cofradía, esto es, la búsqueda de un espacio privativo dentro de las iglesias parroquiales.

Sin ocupar un lugar central en la producción artístico-religiosa de sus parroquias, las cofradías sí que van a cumplir un papel complementario sirviendo, al mismo tiempo, de instrumento de difusión de una determinada vivencia de la fe que viene impuesta por la Iglesia en un intento de unificar de facto el culto y el dogma. Caso paradigmático a este respecto es el de la Cofradía del Rosario.

Llama la atención la rivalidad existente entre cofradías de igual titularidad pero pertenecientes a parroquias diferentes aunque próximas, cómo los encargos tomaban lo realizado en otros lugares como ejemplo y, siempre que fuera posible, mejorándolo, como vemos en el caso de la Cofradía del Rosario de San Mamés de Meruelo y de Castillo.

A través de la actuación de las Cofradías lo que se puede vislumbrar es una pugna que las trasciende tanto a ellas como a las parroquias en las que se alojan. Se trataría de la disputa entre una fuerza "uniformizadora" por parte de la Iglesia que se pretende imponer conforme al principio de jerarquía; y otra "individualizadora" por parte de las gentes que, aun participando de esa fe y compartiendo el mismo dogma, buscan crear sus espacios privativos y diferenciadores, a veces manteniendo una tradición heredada, a veces iniciando esa tradición.

\section{Bibliografía}

ARAMBURU-ZABALA HIGUERA, Miguel Ángel (dir.), Catálogo Monumental de las Cuencas del Asón y Agüera. Tomo II: Municipios de Limpias, Ramales de la Victoria, Rasines, Ruesga y Villaverde de Trucíos, Santander, Asociación grupo acción local Asón-Agüera, 2001.

ARIAS DE SAAVEDRA ALÍAS, Inmaculada y LÓPEZ-GUADALUPE MUÑOZ, Miguel Luis, “Las cofradías religiosas y su dimensión social en la España del Antiguo Régimen", Cuadernos de Historia Moderna, 25 
(2000), pp. 189-232.

BARRÓN GARCÍA, Aurelio Á., La época dorada de la platería burgalesa: 14001600, Salamanca, Junta de Castilla y León, Consejería de Educación y Cultura, Diputación Provincial de Burgos, 1998.

BARRÓN GARCÍA, Aurelio Á. y ESPEJO-SAAVEDRA, Rocío, La pintura mural en Valdeolea y su entorno, Santander, Fundación Marcelino Botín, 1998.

CAMPUZANO RUIZ, Enrique, Retablos de Cantabria, Santander, Caja Cantabria, 1989.

CASADO SOTO, José Luis, Cantabria en los siglos XVI y XVII. Historia General de Cantabria. Tomo V, Santander, Tantín, 1986.

CASADO SOTO, José Luis, Cantabria vista por los viajeros de los siglos XVI y XVII, Santander, Centro de Estudios Montañeses, 2000.

COFIÑO FERNÁNDEZ, Isabel y MAZARRASA MOWINCKEL, Karen, Ermitas, capillas y santuarios de Cantabria, Santander, Colegio Oficial de Aparejadores y Arquitectos Técnicos de Cantabria, 2006.

COFIÑO FERNÁNDEZ, Isabel, Arquitectura religiosa en Cantabria (16851754), Santander, Universidad de Cantabria, 2004.

COFIÑO FERNÁNDEZ, Isabel, "Promoción artística en las Montañas Bajas del Arzobispado de Burgos: la arquitectura religiosa", Altamira, 58 (2001), pp. 7-56.

ESCALLADA GONZÁLEZ, Luis, Historia del Valle de Meruelo. Siete Villas en el Antiguo Régimen. Fuentes documentales, Santander, Ayuntamiento de Meruelo, 1998.

FONSECA MONTES, Josué, El clero en Cantabria en la Edad Moderna, Santander, Universidad de Cantabria, 1996.

FONSECA MONTES, Josué, “La Contrarreforma en Cantabria”, en I Encuentro de Historia de Cantabria, Santander, Universidad de Cantabria/Gobierno de Cantabria, 1999, pp. 837-854.

FONSECA MONTES, Josué, "Las cofradías en Cantabria: elementos para la comprensión de una estructura socio-religiosa significativa en los siglos XVI-XVIII", Espacio, Tiempo y Forma, Serie IV, Historia Moderna, 20 (2007), pp. 43-71.

GIL AGUIRRE, Elena, "Arte y patrocinio. La impronta de la clientela en el Barroco cántabro", Trasdós, 1 (1999), pp. 63-73.

GÓMEZ RODRÍGUEZ, Eduardo, “Una aproximación al estudio de la creación de la Diócesis de Santander", Cimas: Ciencia, Literatura y Pensamiento, 1 (2017), pp. 41-48.

GÓMEZ MARTÍNEZ, Javier y POLO SÁNCHEZ, Julio J., “La parroquial de Nuestra Señora de las Lindes en Suances: proceso de construcción y ornamentación del edificio parroquial. Cofradías y tradiciones", $A l$ - 
tamira, 48 (1989), pp. 143-175.

GONZÁLEZ ECHEGARAY, Joaquín, "Estructura eclesiástica y niveles de poder en la Cantabria del siglo XVII" en VV.AA., Población y sociedad en la España Cantábrica durante el siglo XVII, Santander, Institución Cultural de Cantabria, 1985, pp. 9-49.

GONZÁLEZ ECHEGARAY, María del Carmen, Documentos para la historia del arte en Cantabria: (escultores, entalladores y pintores de los siglos XVI al XVIII), Tomo I, Santander, Diputación provincial de Santander, 1971.

GONZÁLEZ ECHEGARAY, María del Carmen, Documentos para la historia del arte en Cantabria: (escultores, entalladores y pintores de los siglos XVI al XVIII), Tomo II, Santander, Diputación provincial de Santander, 1973.

MANTECÓN MOVELLÁN, Tomás A., “Cofradías religiosas y religiosidad popular en la Cantabria Moderna" en MARURI VILLANUEVA, Ramón (ed.), La Iglesia en Cantabria, Santander, Obispado de Santander, 2000, pp. 243-266.

MANTECÓN MOVELLÁN, Tomás A., "El papel social de las cofradías tridentinas en Cantabria. Siglos XVII al XIX", Altamira, 47 (1988), pp. 227-260.

MANTECÓN MOVELLÁN, Tomás A., Contrarreforma y religiosidad popular en Cantabria. Las cofradías religiosas, Santander, Universidad de Cantabria/Asamblea Regional de Cantabria, 1990.

MARURI VILLANUEVA, Ramón, "Vida religiosa en la Cantabria del Antiguo Régimen", en MARURI VILLANUEVA, Ramón (ed.), La Iglesia en Cantabria, Santander, Obispado de Santander, 2000, pp. 203-223.

POLO SÁNCHEZ, Julio J. (ed.), Catálogo del patrimonio cultural de Cantabria. Tomo II: La Merindad de Trasmiera: Juntas de Ribamontan, Siete Villas y Voto, Villas de Escalante y Santoña, Santander, Consejería de Cultura y Deporte del Gobierno de Cantabria, 2001.

POLO SÁNCHEZ, Julio J. (ed.), Catálogo del patrimonio cultural de Cantabria. Tomo I: La Merindad de Trasmiera: Juntas de Cudeyo y Cesto, Santander, Consejería de Cultura y Deporte del Gobierno de Cantabria, 2000.

POLO SÁNCHEZ, Julio J., "Arte y religiosidad en las "Montañas Bajas" del arzobispado de Burgos", Trasdós, 1 (1999), pp. 63-94.

POLO SÁNCHEZ, Julio J., La escultura romanista y contrarreformista en Cantabria (c. 1590-1660), Santander, Fundación Marcelino Botín, 1994.

RODRÍGUEZ FERNÁNDEZ, Agustín, Los Carabeos. Historia, economía y sociedad en un concejo rural de la Merindad de Campoo, Santander, Centro de Estudios Montañeses/Institución Cultural de Cantabria, 1979.

ZUBIETA IRÚN, José Luis, Geografía histórica de la Diócesis de Santander, Santander, Universidad de Cantabria, 2008. 
